\title{
End Effect of Sheet Plasma
}

\section{シートプラズマの端効果}

Katsuhiko SUNAKO, Yasuhiro OGAWA, Masahiro SUMIYA, Norio MIURA ${ }^{\mathrm{a}}$, Kenzo NANRI ${ }^{\mathrm{b}}$, Kazutaka KAWAMURA ${ }^{\mathrm{b}}$ and Kazuo TAKAYAMA $^{\mathrm{b}}$

Department of Physics, School of Science

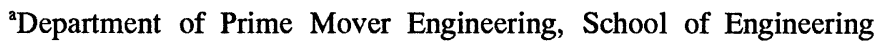

binstitute of Research and Development

Tokai University, 1117 Kitakaname, Hiratsuka, Kanagawa 259-12, Japan

( Accepted for publication 26 November 1992 )

\section{I. 緒铪}

本学で開発したTU-2号機で生成されたシートプラズマは次 のような特徴を有している。

（1）定常である。

（2）高密度である。（カスプ磁場と浮動電極で放電路を 圧縮している。）

（3）高電離である。（差動排気しているためプラズマ領 域のガス圧が放電領域より $10^{3} \sim 10^{4}$ 倍低くなっており プラズマと中性粒子との衝突が少なくなっている。)

(4) 幅方向の密度分布, 温度分布, プラズマ電位分布が 一様である。

この研究はシートプラズマの端（アノード後方 $31 \mathrm{~cm}$ ）に ターゲットを設置しターゲットがプラズマに及ばす影響を調 べることにある。測定はアノード後方 $13 \mathrm{~cm}$ の位置にある シングルプローブをシートプラズマの厚さ方向に $1 \mathrm{~mm}$ 刻み 移動させて行った。この実験結果はプラズマと壁との相互 作用，とくにプラズマにより壁に生成される浮動電位がプラ ズマにおよぼす影響を理解する上で重要になってくる。

\section{II. 実験方法}

Fig.1 が TPD 型シートプラズマ生成装置 TU-2 号機の概 念図である。熱陰極グロー放電プラズマはアノードの後方 にシートプラズマとして生成される。そのシートプラズマ の端を開放にした場合とセラミック板, 浮動 Mo 板及びMo 板をアースしたものを取付, 放電電流 $5,10,15,20 \mathrm{~A}$ と変 化させ，それぞれの場合にプローブ測定を行った。

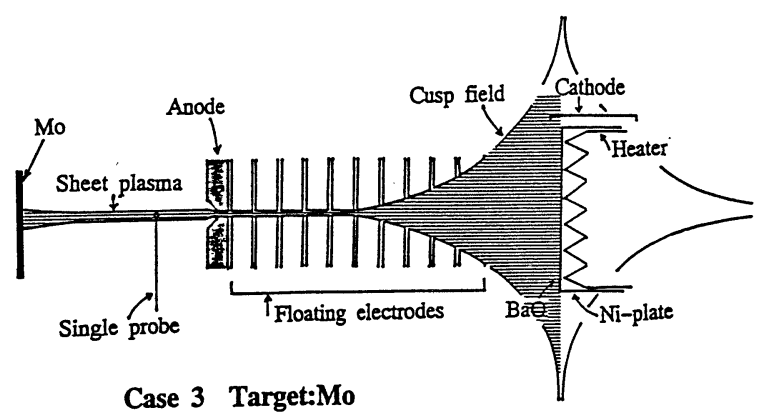

Fig.1 Schematic diagram of experimental appatus with Mo target.
使用ガスは Ar，アノード近傍の磁場強度は $0.15 \mathrm{~T}$ ，熱㓌極 のヒーター入力は $1.5 \mathrm{~kW}$ である。

\section{III. 実検結果}

電子密度 : ・プラズマ端開放よりセラミックの方が分布の半 分布值幅が増大する。

・MoとMo+earthの差は小さいが, 前者より半值 幅が狭くなり中心部での密度の増大は大きい。

・ Fig.2 が放電電流 20A のときの一例である。

電子温度 : ・密度分布と同じ傾向を示す。

分布

プラズマ：・プラズマ端が開放の時，中心部の電位が最も低 電位分布〈なる。

- Mo と Mo+earth の差は小さいが, 前者より 中心部の電位は 2 倍高くなり, 半值幅も増大す る。
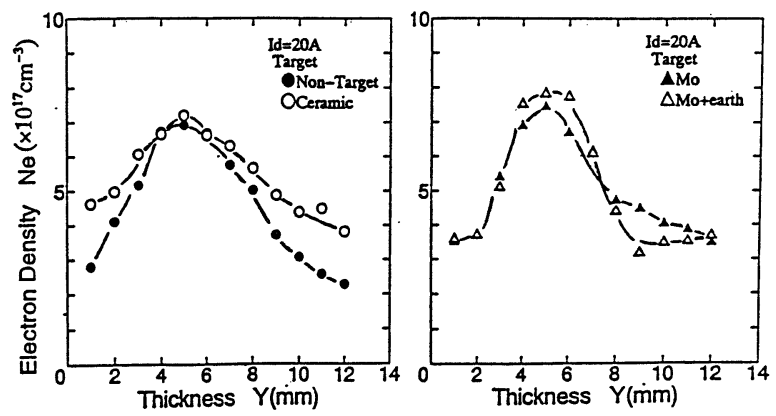

(a) Non-Target and Ceramic (b) Mo and Mo+Earth Fig.2 Electron density distribution.

\section{IV. 結咅}

・ターゲットの効果が電子密度, 電子温度, プラズマ電位の 各分布に明膫に現れた。

・ターゲットによりプラズマ物理量の制御が可能になった。

92 SAS Intelligent Symposium 